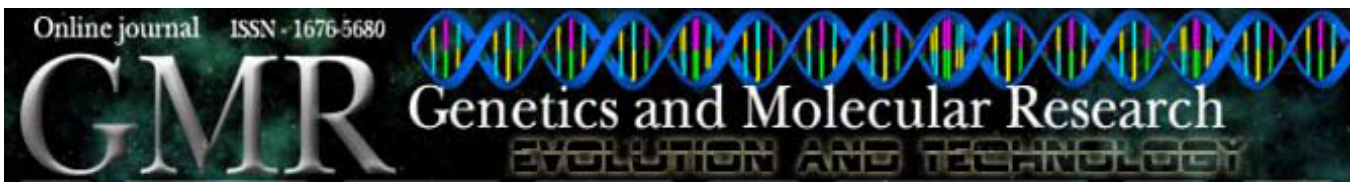

\title{
$\alpha$-Thalassemia (3.7 kb deletion) in a population from the Brazilian Amazon region: Santarém, Pará State
} \author{
Universidade Federal do Pará, Belém, PA, Brasil \\ Corresponding author: J.F. Guerreiro \\ E-mail: joaofg@ufpa.br \\ Genet. Mol. Res. 8 (2): 477-481 (2009) \\ Received January 1, 2009 \\ Accepted March 9, 2009 \\ Published April 28, 2009
}

A.E.S. Souza, G.L. Cardoso, S.Y.L. Takanashi and J.F. Guerreiro

Laboratório de Genética Humana e Médica, Instituto de Ciências Biológicas,

ABSTRACT. The ethnic composition of the Brazilian population favors high frequencies of the - $\alpha 3.7$ deletion, responsible for $\alpha$-thalassemia, because this mutation is very common in African populations. In spite of its importance, this hemoglobinopathy has been poorly investigated in Brazil, especially at the molecular level. We investigated the prevalence of the $-\alpha 3.7$ mutation in 220 individuals attended at the Municipal Hospital of Santarém, in the State of Pará. These patients were distributed into three different groups: i) 103 individuals with anemia who had microcytosis and hypochromia, ii) 11 individuals without anemia who had microcytosis and hypochromia, and iii) 106 individuals with no hematological alterations. We examined the usefulness of investigating $\alpha$-thalassemia carrier status for microcytosis. Among the 103 patients with anemia, $20(19.4 \%)$ were heterozygotes $(-\alpha 3.7 / \alpha \alpha)$ and one $(1.0 \%)$ was a homozygote $(-\alpha 3.7 /-\alpha 3.7)$. Among the 11 patients without anemia, one heterozygote $(-\alpha 3.7 / \alpha \alpha)$ was identified; in the third group, composed of normal individuals (106 samples), deletion - $\alpha 3.7$ was found in seven samples $(6.6 \%)$, all of which were heterozygotes $(-\alpha / \alpha \alpha)$. These frequencies are within the expected range, given available data on the distribution of this hemoglobin disorder in human popu- 
lations and the ethnic composition of the population of Santarém. We found that $\alpha$-thalassemia is a common cause of microcytosis, given that a high proportion (19.2\%) of the microcytic population carried $\alpha$-globin gene deletions.

Key words: Alpha-thalassemia; - $\alpha 3.7$ deletion; Brazilian population

\section{INTRODUCTION}

$\alpha$-Thalassemia, the most common single-gene disease in the world, is characterized by a reduction or complete absence of $\alpha$-globin gene expression. Two different deletions $(-\alpha 3.7$ and $-\alpha 4.2)$ in the $\alpha$-globin gene on chromosome $16 p 13.3$, originating from homologous recombination between misaligned chromosomes, are the most common cause of $\alpha$-thalassemia (Higgs et al., 1989). The deletion of $3.7 \mathrm{~kb}$ of DNA (rightward $\alpha+-$ thalassemia) is found worldwide, but it is most prevalent in some African, Indian, Nepalese, Sardinian and many other Mediterranean populations, Chinese, and other East Asian populations. The $-\alpha 4.2$ deletion (leftward $\alpha+$-thalassemia) also has a worldwide distribution, but it is more commonly found in Indian, Melanesian, Thai, and some other Southeast Asian populations (Huisman et al., 1997; Weatherall et al., 2001). In the few studies carried out in Brazilian populations - $\alpha 3.7$ deletion was the most common deletion. Sonati et al. (1991) found $\alpha 3.7$ thalassemia at frequencies varying from 20.0 to $25.0 \%$ in a sample of black individuals from Campinas, São Paulo State. Borges et al. (2001) studied 339 adult outpatients with microcytosis and hypochromia without anemia seen at the University of Campinas Hospital and found 49.9\% with $\alpha$-thalassemia (169 individuals), 145 (42.8\%) heterozygotes $(-\alpha 3.7 / \alpha \alpha)$ and $18(5.3 \%)$ homozygotes $(-\alpha 3.7 /-\alpha 3.7)$. In the Northeast, $-\alpha 3.7$ deletion was investigated by Couto et al. (2003) in 106 pregnant women with AC and AA hemoglobin pattern, and $21.7 \%$ silent carriers $(-\alpha 3.7 / \alpha \alpha)$ and $0.9 \%$ thalassemic trait

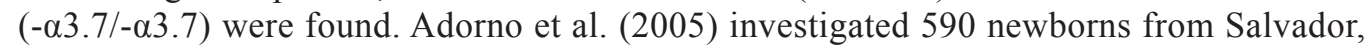
Bahia, and observed that one hundred and fourteen $(22.2 \%)$ had $\alpha 3.7$ thalassemia, of whom $101(19.7 \%)$ were heterozygous and 13 (2.5\%) homozygous.

Carriers of the $\alpha$-gene deletion have mild microcytosis and hypochromia, and although anemia is either absent or unremarkable, it is important to diagnose $\alpha$-thalassemia in order to identify the cause of microcytosis and to avoid repeated expensive analysis and/or prevent either unnecessary or prolonged iron supplementation. In this study, we investigated the prevalence of the - $\alpha 3.7$ mutation to evaluate the importance of $\alpha$-thalassemia carrier status for microcytosis in 220 individuals of the population of Santarém, mid-Amazon region, Pará State. The subjects were distributed into three different groups, individuals with microcytosis and hypochromia with anemia, individuals with microcytosis and hypochromia without anemia, and individuals without hematologic alteration.

\section{SUBJECTS AND METHODS}

\section{Subjects}

The study sample was made up of 220 patients seen at the Municipal Hospital of San- 
tarém, Pará State, northern Brazil. All the participants were informed about the study and gave their written consent. The sample was divided into three groups: i) 103 individuals with microcytosis and hypochromia with anemia (mean corpuscular volume $<80 \mathrm{fL}$, and mean corpuscular hemoglobin $<27 \mathrm{pg}$ ), hemoglobin $<12 \mathrm{~g} / \mathrm{dL}$ for women and $<14 \mathrm{~g} / \mathrm{dL}$ for men, ii) 11 individuals with microcytosis and hypochromia without anemia, and iii) 106 individuals with no hematological alteration.

\section{Hematological, DNA and statistical analyses}

Hematological analysis was carried out at the Clinical Analysis Laboratory of the Municipal Hospital of Santarém and at Laboratory Celso Matos. Red blood cell indices were electronically determined. DNA samples were obtained from peripheral blood leukocytes by the phenol-chloroform method (Old and Higgs, 1993). - $\alpha 3.7$ deletion was investigated using the multiplex gap-polymerase chain reaction method (Liu et al., 2001). Statistical analysis was carried out using the statistical package BioStat version 5.0 (Ayres et al., 2007), and an independent sample $t$-test was used for comparison of hematological parameters. Allele and genotype frequencies were estimated by gene counting.

\section{RESULTS}

The initial analysis of hematological parameters was done on 202 samples. Of these samples, 114 displayed microcytosis and hypochromia, 103 with anemia and 11 without anemia. Of the 103 patients with anemia, 20 (19.4\%) were heterozygotes (- $\alpha 3.7 /$ $\alpha \alpha)$ and one (1.0\%) was homozygote $(-\alpha 3.7 /-\alpha 3.7)$. The carrier status in these 103 patients was $20.4 \%$, and the frequency of the $-\alpha 3.7$ deletion in this group was $10.7 \%$. Among the 11 patients without anemia, the $-\alpha 3.7$ deletion was identified in only one patient, a silent carrier $(-\alpha / \alpha \alpha)$, and the frequency of $-\alpha 3.7$ deletion in this group was $4.5 \%$. In the third group, formed by normal individuals (106 samples), $\alpha$-thalassemia due to deletion $-\alpha 3.7$ was $6.6 \%$ (7 samples), all heterozygotes $(-\alpha / \alpha \alpha)$. The frequency of mutation in this group was $3.3 \%$ (Table 1). Table 2 shows the hematological data (mean and standard deviation) of $\alpha$-thalassemia carriers compared with those of patients with normal $\alpha$-genes. As expected, the mean corpuscular volume and mean corpuscular hemoglobin values among thalassemic carriers were lower than those found among the non-thalassemic ones from the sample without hematological alterations. However, it should be considered that the hematological parameters exhibited by the thalassemic carriers were also certainly influenced by iron deficiency, which was not evaluated in this study.

\begin{tabular}{|c|c|c|c|c|c|}
\hline Sample & $\mathrm{N}$ & $\alpha \alpha / \alpha \alpha$ & $-\alpha 3.7 / \alpha \alpha$ & $-\alpha 3.7 /-\alpha 3.7$ & $-\alpha 3.7$ \\
\hline Microcytic hypochromic anemia & 103 & $82(79.6 \%)$ & $20(19.4 \%)$ & $1(1.0 \%)$ & $10.7 \%$ \\
\hline Microcytosis and hypochromia without anemia & 11 & $10(90.9 \%)$ & $1(9.1 \%)$ & & $4.5 \%$ \\
\hline No hematological alterations & 106 & $99(93.4 \%)$ & $7(6.6 \%)$ & & $3.3 \%$ \\
\hline Overall & 220 & $191(86.8 \%)$ & $28(12.7 \%)$ & $1(0.5 \%)$ & $6.8 \%$ \\
\hline
\end{tabular}




Table 2. Hematological data, reported as means $\pm \mathrm{SD}$, of patients with and without $\alpha$-thalassemia.
\begin{tabular}{lccc}
\hline Hematological data & Normal $\alpha$-genes $(\mathrm{N}=191)$ & $-\alpha 3.7$ thalassemia carriers $(\mathrm{N}=29)$ & $\mathrm{P}$ \\
\hline $\mathrm{Hb}(\mathrm{g} / \mathrm{dL})$ & $12.8 \pm 1.76$ & $11.1 \pm 1.67$ & 0.008 \\
$\mathrm{MCV}(\mathrm{fL})$ & $81.827 \pm 10.827$ & $72.2 \pm 9.162$ & 0.000 \\
$\mathrm{MCH}(\mathrm{pg})$ & $27.076 \pm 3.078$ & $23.9 \pm 3.342$ & 0.000 \\
$\mathrm{Hct}$ & $36.289 \pm 5.597$ & $33.5 \pm 4.991$ & 0.009 \\
\hline
\end{tabular}

$\mathrm{Hb}=$ hemoglobin; $\mathrm{MCV}=$ mean corpuscular volume; $\mathrm{MCH}=$ mean corpuscular hemoglobin; $\mathrm{Hct}=$ hematocrit.

\section{DISCUSSION}

The prevalence of $\alpha$-thalassemia observed in 103 patients with microcytic and hypochromic anemia from the population of Santarém (19.4\% silent carriers, - $-\alpha 3.7 / \alpha \alpha$ genotype, and $1 \%$ with thalassemic trait, $-\alpha 3.7 /-\alpha 3.7$ genotype) was similar to that found by Pereira et al. (2002) in microcytic hypochromic anemia patients from the population of Belém, PA, where the silent carrier and thalassemic trait phenotypes were found with frequencies of 17.3 and $4.5 \%$, respectively. These two populations have similar genetic backgrounds, resulting from the miscegenation between European, mostly Portuguese, and African, and indigenous people, in quite close proportions (Santos et al., 1996). This can explain their similar frequencies of the - $\alpha 3.7$ mutation. The paucity of data on $\alpha$-thalassemia genotyping in Brazil and the sample heterogeneity of the studies available hinder the comparison of our results with those obtained in other Brazilian populations.

Inherited hemoglobin disorders have not been found in Amerindians and no $\alpha$-globin gene deletion was found in the five Amerindian tribes studied to date, although the triplicate $\alpha$-globin gene chromosome was found at relatively high frequencies in two tribes (Zago et al., 1995). Therefore, the deletion was probably brought to the Amazonian area predominantly by African slaves and by Portuguese settlers to a lesser degree. The results observed in Santarém are in agreement with those expected based not only on the available data about the distribution of this hemoglobin disorder in human populations, but also on the ethnic composition of the population of Santarém, whose contributions of Portuguese, African, and indigenous people have been estimated at 37, 28, and 35\%, respectively (Santos et al., 1996).

Microcytic hypochromic anemia is a common hematological abnormality in clinical practice and it is usually caused by iron deficiency and thalassemia ( $\alpha$ and/or $\beta$, depending on the ethnic diversity of the population). Our results point out that the ethnic diversity of the Santarém population makes $\alpha$-thalassemia a common cause of microcytosis, given that a significant proportion (19.2\%) of the microcytic population carries the $\alpha$-globin gene deletion(s), indicating the importance of investigating, besides serum iron levels, the $\alpha$-thalassemia carrier status for microcytosis, to prevent unnecessary and potentially harmful medical intervention and iron therapy in patients with microcytic anemia due to thalassemia.

\section{ACKNOWLEDGMENTS}

Research supported by the National Council for Scientific and Technological Development (CNPq) and the Federal University of Pará, Brazil. 


\section{REFERENCES}

Adorno EV, Couto FD, Moura Neto JP, Menezes JF, et al. (2005). Hemoglobinopathies in newborns from Salvador, Bahia, Northeast Brazil. Cad. Saude Publica 21: 292-298.

Ayres M, Ayres M Jr, Ayres DL and Santos AS (2007). Bioestat: 5.0. Aplicações Estatísticas nas Áreas das Ciências Biológicas e Médicas. Sociedade Civil Mamirauá, MCT - CNPq, Belém.

Borges E, Wenning MR, Kimura EM, Gervasio SA, et al. (2001). High prevalence of alpha-thalassemia among individuals with microcytosis and hypochromia without anemia. Braz. J. Med. Biol. Res. 34: 759-762.

Couto FD, De Albuquerque AB, Adorno EV, De Moura Neto JP, et al. (2003). alpha-Thalassemia 2, 3.7 kb deletion and hemoglobin AC heterozygosity in pregnancy: a molecular and hematological analysis. Clin. Lab. Haematol. 25: 29-34.

Higgs DR, Vickers MA, Wilkie AO, Pretorius IM, et al. (1989). A review of the molecular genetics of the human alphaglobin gene cluster. Blood 73: 1081-1104.

Huisman THJ, Carver MFH and Baysal E (1997). A Syllabus of Thalassemia Mutations. The Sickle Cell Anemia Foundation, Augusta.

Liu YT, Old JM, Miles K, Fisher CA, et al. (2000). Rapid detection of alpha-thalassaemia deletions and alpha-globin gene triplication by multiplex polymerase chain reactions. Br. J. Haematol. 108: 295-299.

Old JM and Higgs DR (1993). Gene analysis. The thalassemias. In: Methods in Hematology (Weatherall DJ, ed.). Churchill Livingstone, Edinburg, 74-102.

Pereira JM, Cardoso GL, Hamoy IG, Silva CB, et al. (2002). Diagnóstico Molecular e a Prevalência da Talassemia-alfa em Indivíduos com Anemia Microcítica e Hipocrômica na Cidade de Belém/PA. In: $48^{\circ}$ Congresso Nacional de Genética, Águas de Lindóia. A Genética na Inclusão Social. Sociedade Brasileira de Genética, Águas de Lindóia.

Santos EJM, Ribeiro-dos-Santos AKC, Guerreiro JF, Aguiar GFS, et al. (1996). Migration and change of ethnic structure in a hybrid population from the Amazon Region (Santarém, Pará). Braz. J. Genet. 9: 511-515.

Sonati MF, Farah SB, Ramalho AS and Costa FF (1991). High prevalence of alpha-thalassemia in a black population of Brazil. Hemoglobin 15: 309-311.

Weatherall DJ, Clegg JB, Higgs DR and Wood WG (2001). The hemoglobinopathies. In: The Metabolic and Molecular Basis of Inherited Disease (Scriver CR, Beaudet AL, Valle D and Sly WS, eds.). McGraw Hill, New York, 4571-4636.

Zago MA, Melo Santos EJ, Clegg JB, Guerreiro JF, et al. (1995). Alpha-globin gene haplotypes in South American Indians. Hum. Biol. 67: 535-546. 